\title{
Elementary School Student Learning Independence Analyst during the Covid-19 Pandemic
}

\author{
Kisman*, A. Hari Witono, Moh. Irawan Zain \\ Elementary School Teacher Education Study Program, FKIP, University of Mataram, Jl. \\ Majapahit No 62 Mataram, 83125, Indonesia \\ *Corresponding Author e-mail: kismanmuhammad448@gmail.com
}

Received: November 2021; Revised: November 2021; Published: December 2021

\begin{abstract}
Independent learning is an important element in learning. Independent learning is defined as a learning process within a person in achieving certain goals that are required to be active individually or not to depend on others, including teachers. This study aims to find out how independent student learning is during the Covid-19 pandemic and the factors causing difficulties in student learning independence during the Covid-19 pandemic class V SD Negeri 46 Mataram. The research approach used is descriptive qualitative research. The data collection instruments used interview questionnaires, observation sheets, and documentation studies. The data analysis technique used is data reduction, data presentation, conclusion or verification. The results show that the learning independence experienced by class V students includes: (1) aspects of having self-confidence reaching an average percentage of $50.3 \%$, (2) aspects in making decisions reached an average percentage of 38.6\%, (3) responsible aspects reached an average percentage of 50\%, (4) aspects of having a competitive desire to advance reached an average percentage of $44.6 \%$, (5) the discipline aspect reached an average percentage of $41.5 \%$. Then the student's learning independence factor in terms of self-confidence, the average percentage is $44.33 \%$. Then the student's learning independence factor in a decision, the average percentage is $36.66 \%$. Then the independent learning factor of students in terms of responsibility, the average percentage is $45.75 \%$. Then the student's learning independence factor in terms of the desire to compete to advance, the average percentage is $38.66 \%$. Then the student's learning independence factor in terms of discipline, the average percentage is $50 \%$.
\end{abstract}

Keywords: Independent student learning, online learning, elementary school, covid-19

How to Cite: Kisman, K., Witono, A., \& Zain, M. (2021). Elementary School Student Learning Independence Analyst during the Covid-19 Pandemic. Prisma Sains : Jurnal Pengkajian Ilmu dan Pembelajaran Matematika dan IPA IKIP Mataram, 9(2), 259-266. doi:https://doi.org/10.33394/j-ps.v9i2.4367

https://doi.org/10.33394/j-ps.v9i2.4367

Copyright@ 2021, Kisman et al This is an open-access article under the CC-BY License.

\section{INTRODUCTION}

Student learning independence is still an obstacle (Isnaeni, et al., 2018). Various levels of difficulty experienced by students in independent learning ranging from lack of understanding of concepts to lack of learning motivation ( $\mathrm{Ng}$, et al., 2016). This affects the learning outcomes achieved and the character that is embedded far from targets and expectations (Dzhengiz, 2020). Independence is a thing or condition where students want to learn without depending on others (Hidayat, et al., 2020). Hasibuan, et al (2019) defines that independence is an aspect of personality that must be achieved in individuals to face challenges and achieve success in life which is indicated by an attitude of freedom, responsibility, consideration, feeling safe when different from others and creativity. Learning is a process within individuals who interact with the environment to get changes in their behavior. According to Ramdani, et al (2021) learning is a mental or psychic activity that takes place in active interaction with the environment that produces changes in knowledge, skills and attitudes. The interactions that occur during the learning process are influenced by the environment consisting of students, teachers, principals, teaching materials, and learning resources. Teaching and learning activities contain several components including objectives, lesson materials, teaching and learning activities, methods, tools and resources, and evaluation. The components of teaching and learning are interrelated and cannot be separated from one another, including independent learning. Likewise with students, students can do independent learning based on their own desires without coercion from 
anyone, independent from others, have self-confidence, behave disciplined, have a sense of responsibility and exercise self-control.

Independent learning is carried out for several reasons, for example because the world is currently faced with an outbreak of a disease caused by a virus called Coronavirus Diseases or known as Covid-19. On January 30, 2020, WHO declared it a public health emergency of concern to the world. The impact of Covid-19 in Indonesia is currently quite large for the entire community. With the continued increase in positive cases of the corona virus in Indonesia, urging the Indonesian government to immediately deal with the Covid-19 pandemic by making various policies such as implementing physical distancing, PSBB (large-scale social restrictions), and lockdown.

According to information obtained by the researcher from the fifth grade teacher at SD Negeri 46 Mataram on Thursday, March 25, 2021, that the school at SD Negeri 46 Mataram held a meeting once a week to take independent assignments, especially grade $\mathrm{V}$ students entered on Thursday and the implementation of online or online learning at schools has been carried out, in online learning in class V, teachers usually use Whatsapp groups and Youtube. Supported by facilities that support online learning, besides that the teacher makes preparations before the learning process takes place. The fifth grade teacher also makes learning videos or downloads videos from the internet as a learning medium for students, and several times a week the fifth grade teacher conducts lessons through Whatsapp groups and Youtube to explain learning materials.

The results of research conducted by Gunawan, et al (2021); Hidayat, et al (2020) that students (students/students) are not quite ready to study online, the cause is due to study habits, and less supportive technology. Factors causing difficulties faced by students in online learning such as, the location of the house is not covered by the internet network, including minimalist student internet quotas, the learning media used by teachers is dominantly monotonous and makes students feel bored or bored, dominant learning is not interactive, character or behavior students are difficult to monitor, learning tends to be online assignments, assignments given to students pile up (Abbas and Hidayat, 2018).

Difficulties faced by students in learning from: the location of the house is not covered by the internet network, including the limited internet quota of students, the learning media used by the teachers is dominantly monotonous and makes the students feel bored or bored, the dominant learning is not yet interactive, the character or behavior of the students is difficult monitored, learning tends to be online assignments, assignments given by students pile up.

\section{METHOD}

This study uses a descriptive qualitative approach. In the opinion (Arikunto, 2013), descriptive research is research that is intended to investigate the circumstances, conditions or other things that have been mentioned, the results of which are presented in the form of a research report. Research that produces descriptive data in the form of written or spoken words from people and observed behavior.

This research was conducted at SD Negeri 46 Mataram. The subjects of this study were the principal, class teacher, fifth grade students and parents. Sources of data in this study are words and actions, the rest are additional data such as documents and others. The data collection instruments used interview questionnaires, observation sheets, and documentation studies. The indicators of student learning independence used in this study consisted of 5 aspects, namely: self-confidence, decision-making, responsibility, desire to compete for progress and discipline. Data analysis techniques consist of data reduction, data presentation, and drawing conclusions. As for the validity of the data test with data triangulation techniques. The triangulation technique in this study uses data triangulation and source triangulation, carried out by checking the data that has been obtained through the subjects, namely the principal, class teacher, parents and fifth grade students at SD Negeri 46 Mataram as an informant in this study.

\section{RESULTS AND DISCUSSION}

The results of research that has been carried out on fifth grade students at SD Negeri 46 Mataram, regarding student learning independence during the covid-19 pandemic. Shows that there are 6 students whose learning independence data is taken. Student Learning Independence in the Covid-19 Pandemic Period Case Study for Class V SD Negeri 46 Mataram grouped into 5 aspects, namely aspects of having self-confidence, Making Decisions, being responsible, having a competitive desire to advance, and discipline. Students that have observed indicators were marked with a check mark $(\sqrt{ })$, while the opposite were marked with a minus mark $(-)$. 


\section{Aspects of having self-confidence}

The results of the analysis of learning independence on the aspect of self-confidence are presented in Table 1.

Table 1. Student Learning Independence: Having Self-confidence

\begin{tabular}{ccccc}
\hline \multirow{2}{*}{$\begin{array}{c}\text { Student's } \\
\text { name }\end{array}$} & $\begin{array}{c}\text { Students are always } \\
\text { confident in expressing } \\
\text { themselves during the } \\
\text { online learning process }\end{array}$ & $\begin{array}{c}\text { Students are confident } \\
\text { in answering questions } \\
\text { during the online } \\
\text { learning process }\end{array}$ & $\begin{array}{c}\text { Students are confident in } \\
\text { asking things they do not } \\
\text { understand during the } \\
\text { online learning process }\end{array}$ & $\begin{array}{c}\text { Average } \\
\text { CAN }\end{array}$ \\
\cline { 2 - 5 } & - & $\checkmark$ & $\checkmark$ \\
BC & - & - & $\checkmark$ \\
CR & $\checkmark$ & - & $\checkmark$ \\
DW & $\checkmark$ & - & $\checkmark$ \\
MR & - & - & - \\
Amount & 3 & 2 & 4 \\
Percentage & $50 \%$ & $33 \%$ & $68 \%$ & $50.33 \%$ \\
\hline
\end{tabular}

Confidence in the aspect of building student confidence in expressing opinions related to the online learning process, seen in Table 1 which states that in indicator (1) the percentage of students always confident in expressing their opinions during the online learning process there are 3 students with a percentage of $50 \%$. In indicator (2), the percentage of students who are confident in answering questions during the online learning process is 2 students, with a percentage of 33\%. In indicator (3), the percentage of students who are confident in asking things they do not understand during the online learning process is 4 students, with a percentage of $68 \%$.

\section{Aspects in Making Decisions} Table 2 .

The results of the analysis of learning independence in Making Decisions are presented in

Table 2 Independent Learning of Students: Making Decisions

\begin{tabular}{ccccc}
\hline \multirow{2}{*}{$\begin{array}{c}\text { Student's } \\
\text { name }\end{array}$} & $\begin{array}{c}\text { Students always } \\
\text { make decisions in } \\
\text { solving the } \\
\text { problems given }\end{array}$ & $\begin{array}{c}\text { Students are able to } \\
\text { make decisions to look } \\
\text { back at the answers } \\
\text { given }\end{array}$ & $\begin{array}{c}\text { Students are able to make } \\
\text { decisions in compiling } \\
\text { learning methods }\end{array}$ & $\sum$ \\
\hline CAN & - & - & $\checkmark$ & Average \\
BC & $\checkmark$ & - & - & \\
CR & - & - & - & \\
DW & $\checkmark$ & $\checkmark$ & - & \\
LSR & - & - & 3 & $38.66 \%$ \\
MR & - & 2 & $50 \%$ & \\
Amount & 2 & $33 \%$ & & $\checkmark$ \\
Percentage & $33 \%$ & & & \\
\hline
\end{tabular}

Making decisions on the aspect of being able to time to look back at the answers that have been given, and being able to answer the questions given, can be seen in Table 2 which states that in indicator (1) the percentage of students who can complete compiling the questions given there are 2 students with a percentage $33 \%$. In indicator (2) the percentage of students able to make decisions to review the answers given, there are 2 students, with a percentage of $33 \%$. In indicator (3) students are able to make decisions in compiling learning methods, namely there are 3 students, with a percentage of $50 \%$.

\section{Aspects of being responsible}

The results of the analysis of learning independence on the Aspects of being responsible are presented in Table 3.

Table 3 Student Learning Independence: In Responsibility

\begin{tabular}{cccccc} 
& \multicolumn{4}{c}{ Indicator } & Average \\
\cline { 2 - 5 } $\begin{array}{c}\text { Student's } \\
\text { name }\end{array}$ & Students are always & Students always & Students are able & Students are & $\sum$ \\
& serious in & collect assignments & to participate in \\
participating in & according to what & participating in & able take \\
online learning & has been & group & for completing & \\
\hline
\end{tabular}




\begin{tabular}{cccccc}
\hline & & determined & discussions & assignments & \\
\hline CAN & $\checkmark$ & $\checkmark$ & $\checkmark$ & $\checkmark$ \\
BC & $\checkmark$ & - & - & - & \\
CR & - & - & $\checkmark$ & $\checkmark$ & \\
DW & $\checkmark$ & $\checkmark$ & - & - & \\
LSR & - & $\checkmark$ & - & - & \\
MR & - & 4 & 2 & 5 & $50.25 \%$ \\
Amount & 3 & $68 \%$ & $33 \%$ & $50 \%$ & \\
Percentage & $50 \%$ & &
\end{tabular}

In the aspect of responsibility in giving assignments according to a set schedule and giving questions to students during the online learning process, it can be seen in Table 3 which states that in indicator (1) the percentage of students who are always serious in participating in online learning there are 3 students with $50 \%$ percentage. In indicator (2), the percentage of students always collects assignments according to what has been determined, there are 4 students, with a percentage of $68 \%$. In indicator (3) the percentage of students able to participate in participating in group discussions there are 2 students, with a percentage of $33 \%$. In indicator (4) the percentage of students capable of being responsible for completing assignments there are 3 students, with a percentage of $50 \%$.

\section{Aspects of having a competitive desire to advance}

The results of the analysis of learning independence on Aspects of having a competitive desire to advance are presented in Table 4.

Table 4 Independent Learning of Students: Having a Competitive Desire to Advance

\begin{tabular}{|c|c|c|c|c|}
\hline \multirow[b]{2}{*}{ Student's name } & \multicolumn{3}{|c|}{ Indicator } & Average \\
\hline & $\begin{array}{c}\text { Students always } \\
\text { take care of } \\
\text { themselves during } \\
\text { teaching and } \\
\text { learning activities }\end{array}$ & $\begin{array}{l}\text { Students are able } \\
\text { to activate } \\
\text { themselves during } \\
\text { teaching and } \\
\text { learning activities }\end{array}$ & $\begin{array}{l}\text { Students are able to find out } \\
\text { things that have not been } \\
\text { understood during teaching } \\
\text { and learning activities }\end{array}$ & $\sum$ \\
\hline CAN & - & - & $\checkmark$ & \\
\hline $\mathrm{BC}$ & $\checkmark$ & - & - & \\
\hline CR & - & - & $\checkmark$ & \\
\hline DW & $\checkmark$ & $\checkmark$ & - & \\
\hline LSR & $\checkmark$ & $\checkmark$ & - & \\
\hline MR & - & - & $\checkmark$ & \\
\hline Amount & 3 & 2 & 3 & \\
\hline Percentage & $50 \%$ & $34 \%$ & $50 \%$ & $44.66 \%$ \\
\hline
\end{tabular}

In the aspect of the desire to compete to advance, students are able to maintain themselves, activate themselves and are able to find out, seen in Table 4 which states that in indicator (1) the percentage of students always takes care of themselves during teaching and learning activities there are 3 students with a percentage of $50 \%$. In indicator (2) the percentage of students able to activate themselves during teaching and learning activities there are 2 students, with a percentage of $34 \%$. In indicator (3) the percentage of students able to find out things that have not been understood during teaching and learning activities there are 3 students, with a percentage of $50 \%$.

\section{Discipline Aspect} Table 5.

The results of the analysis of learning independence on the Discipline Aspect are presented in

Table 5 Student Learning Independence: Discipline

\begin{tabular}{cccc}
\multirow{2}{*}{$\begin{array}{c}\text { Student's } \\
\text { name }\end{array}$} & $\begin{array}{c}\text { Students always prepare equipment } \\
\text { before starting online learning }\end{array}$ & $\begin{array}{c}\text { Students do not commit acts that violate } \\
\text { the rules during the online learning } \\
\text { process }\end{array}$ & $\sum$ \\
\hline CAN & $\checkmark$ & - & Average \\
BC & - & - & \\
CR & - & - & \\
DW & $\checkmark$ & $\checkmark$ & \\
LSR & - & $\checkmark$ & $41.5 \%$ \\
MR & - & 3 & \\
Amount & 2 & $50 \%$ & \\
Percentage & $33 \%$ & & \\
\end{tabular}


In the aspect of discipline in preparing equipment during the learning process, it can be seen in Table 5 which states that in indicator (1) the percentage of students always preparing equipment before starting online learning there are 2 students with a percentage of $33 \%$. In indicator (2) the percentage of students not committing acts that violate the rules during the learning process there are 3 students, with a percentage of $50 \%$

\section{Factors of Difficulty in Self-Study for Students during the Covid-19 Pandemic Case Study Class V SD Negeri 46 Mataram}

Based on the results of data collection that has been carried out, it is obtained data related to factors that cause difficulties in student learning independence, researchers collect by arranging interview, observation, and documentation instruments. The factors that cause difficulties in student learning independence for each individual are different, furthermore, it can be seen in the Table 6 .

\section{Difficulty factors for Student Learning Independence: Have self-confidence}

Factor Analysis of Students' Learning Independence Difficulty: Having self-confidence is presented in Table 6.

Table 6 Difficulty Factors for Students' Independent Learning: Have Confidence

\begin{tabular}{ccccc}
\hline & \multicolumn{3}{c}{ Indicator } & Average \\
\cline { 2 - 5 } $\begin{array}{c}\text { Student's } \\
\text { name }\end{array}$ & $\begin{array}{c}\text { Students are always } \\
\text { confident in expressing } \\
\text { themselves during the online } \\
\text { learning process }\end{array}$ & $\begin{array}{c}\text { Students are confident } \\
\text { in answering questions } \\
\text { during the online } \\
\text { learning process }\end{array}$ & $\begin{array}{c}\text { Students are confident in } \\
\text { asking things they do not } \\
\text { understand during the online } \\
\text { learning process }\end{array}$ & $\sum$ \\
CAN & $\checkmark$ & $\checkmark$ & $\checkmark$ \\
BC & - & - & $\checkmark$ \\
CR & - & - & $\checkmark$ \\
DW & $\checkmark$ & $\checkmark$ & $\checkmark$ \\
LSR & $\checkmark$ & - & - \\
MR & - & - & 4 \\
Amount & 3 & 2 & $68 \%$ & $44.33 \%$ \\
Percentage & $50 \%$ & $33 \%$ & \\
\hline
\end{tabular}

The difficulty factor of confidence in the aspect of difficulty in building students' confidence in expressing opinions related to the online learning process, seen in Table 6 which states that in indicator (1) the percentage of students always confident in expressing their opinions during the online learning process there are 3 students with 50\% percentage. In indicator (2), the percentage of students who are confident in answering questions during the online learning process is 2 students, with a percentage of $33 \%$. In indicator (3), the percentage of students who are confident in asking things they do not understand during the online learning process is 3 students, with a percentage of $50 \%$.

\section{Difficulty Factors in Student Learning Independence: In Making Decisions}

Factor analysis of the difficulty of student learning independence in making decisions is presented in Table 7.

Table 7 Factors of Difficulty in Students' Independent Learning: In Making Decisions

\begin{tabular}{ccccc}
\hline \multirow{2}{*}{$\begin{array}{c}\text { Student's } \\
\text { name }\end{array}$} & $\begin{array}{c}\text { Students always make } \\
\text { decisions in solving the } \\
\text { problems given }\end{array}$ & $\begin{array}{c}\text { Students are able to make } \\
\text { decisions to look back at } \\
\text { the answers given }\end{array}$ & $\begin{array}{c}\text { Students are able to make } \\
\text { decisions in compiling } \\
\text { learning methods }\end{array}$ & $\sum$ \\
\hline CAN & - & - & $\checkmark$ \\
BC & $\checkmark$ & $\checkmark$ & - \\
CR & - & - & - \\
DW & $\checkmark$ & - & $\checkmark$ \\
LSR & - & $\checkmark$ & - \\
MR & - & - & 3 \\
Amount & 2 & 2 & $50 \%$ & $36.66 \%$ \\
Percentage & $33 \%$ & $33 \%$ & \\
\hline
\end{tabular}

The difficulty factor in making decisions on the aspect of difficulty in making decisions at the time of reviewing the answers that have been given, and being able to answer the questions given, is seen in Table 7 which states that in indicator (1) the percentage of students can complete compiling the questions. The questions given were 2 students with a percentage of $33 \%$. In indicator (2), the 
percentage of students able to make decisions to review the answers given is 3 students, with a percentage of $50 \%$. In indicator (3) students are able to make decisions in compiling learning methods, namely there are 2 students, with a percentage of $33 \%$.

\section{Difficulty Factors in Student Learning Independence: In Responsibility}

Factor analysis of the difficulty of student learning independence in responsibility is presented in Table 8.

Table 8 Difficulty Factors for Students' Independent Learning: In Responsible

\begin{tabular}{ccccc}
\hline & \multicolumn{3}{c}{ Indicator } & Average \\
\cline { 2 - 6 } $\begin{array}{c}\text { Student's } \\
\text { name }\end{array}$ & $\begin{array}{c}\text { Students are } \\
\text { always serious } \\
\text { in participating } \\
\text { in online } \\
\text { learning }\end{array}$ & $\begin{array}{c}\text { Students always } \\
\text { collect assignments } \\
\text { according to what } \\
\text { has been } \\
\text { determined }\end{array}$ & $\begin{array}{c}\text { Students are able to } \\
\text { participate in } \\
\text { participating in group } \\
\text { discussions }\end{array}$ & $\begin{array}{c}\text { Students are able } \\
\text { to take } \\
\text { responsibility for } \\
\text { completing } \\
\text { assignments }\end{array}$ \\
\hline CAN & $\checkmark$ & $\checkmark$ & & $\checkmark$ \\
BC & $\checkmark$ & - & - & $\checkmark$ \\
CR & - & $\checkmark$ & - & - \\
DW & $\checkmark$ & - & $\checkmark$ & - \\
LSR & - & $\checkmark$ & - & - \\
MR & - & 4 & 2 & 3 \\
Amount & 3 & $68 \%$ & $33 \%$ & $50 \%$ \\
Percentage & $50 \%$ & & & $45,75 \%$ \\
\hline
\end{tabular}

On the aspect of the difficulty factor in being responsible for giving assignments according to a set schedule and giving questions to students during the online learning process, it can be seen in Table 8 which states that in indicator (1) the percentage of students who are always serious in participating in online learning is there 3 students with a percentage of $50 \%$. In indicator (2) the percentage of students always collects assignments according to what has been determined there are 3 students, with a percentage of $50 \%$. In indicator (3) the percentage of students able to participate in participating in group discussions there are 2 students, with a percentage of $33 \%$. In indicator (4) the percentage of students capable of being responsible for completing assignments there are 3 students, with a percentage of $45,75 \%$.

\section{Difficulty Factors in Student Learning Independence: In Having a Competitive Desire To Advance}

Factor analysis of the difficulty of student learning independence in having a competitive desire to advance is presented in Table 9.

Table 9 Difficulty Factors for Students' Independent Learning: In Having a Competitive Desire To Advance

\begin{tabular}{ccccc}
\hline \multirow{2}{*}{$\begin{array}{c}\text { Student's } \\
\text { name }\end{array}$} & $\begin{array}{c}\text { Students always take } \\
\text { care of themselves } \\
\text { during teaching and } \\
\text { learning activities }\end{array}$ & $\begin{array}{c}\text { Students are able to } \\
\text { activate themselves } \\
\text { during teaching and } \\
\text { learning activities }\end{array}$ & $\begin{array}{c}\text { Students are able to find out } \\
\text { things that have not been } \\
\text { understood during teaching } \\
\text { and learning activities }\end{array}$ & $\sum$ \\
\hline CAN & - & - & $\checkmark$ \\
BC & $\checkmark$ & - & - \\
CR & - & - & $\checkmark$ \\
DW & $\checkmark$ & $\checkmark$ & - \\
LSR & $\checkmark$ & - & $\checkmark$ \\
MR & - & 2 & 3 \\
Amount & 3 & $34 \%$ & $50 \%$ \\
Percentage & $50 \%$ & \multicolumn{3}{c}{} \\
\hline
\end{tabular}

In the aspect of the difficulty factor in having a competitive desire to advance, students find it difficult to maintain themselves, activate themselves and be able to find out, seen in Table 9 which states that in indicator (1) the percentage of students always takes care of themselves during teaching and learning activities there are 2 students with a percentage 33\%. In indicator (2) the percentage of students able to activate themselves during teaching and learning activities there are 2 students, with a percentage of $34 \%$. In indicator (3) the percentage of students able to find out things that have not 
been understood during teaching and learning activities there are 3 students, with a percentage of $50 \%$.

\section{Difficulty Factors for Students' Learning Independence: Having Discipline}

The analysis of the difficulty of learning independence for students having discipline is presented in Table 10.

Table 10 Difficulty Factors for Students' Independent Learning: Have Discipline

\begin{tabular}{cccc}
\hline \multirow{2}{*}{$\begin{array}{c}\text { Student's } \\
\text { name }\end{array}$} & $\begin{array}{c}\text { Students always prepare } \\
\text { equipment before starting online } \\
\text { learning }\end{array}$ & $\begin{array}{c}\text { Students do not commit acts } \\
\text { that violate the rules during the } \\
\text { online learning process }\end{array}$ & Average \\
\hline CAN & $\checkmark$ & - & \\
BC & - & $\checkmark$ & \\
CR & - & - & \\
DW & $\checkmark$ & $\checkmark$ & \\
LSR & - & 3 & $50 \%$ \\
MR & - & $50 \%$ & \\
Amount & 2 & & \\
Percentage & $33 \%$ & &
\end{tabular}

In the aspect of discipline in preparing equipment during the learning process, it can be seen in Table 10 which states that in indicator (1) the percentage of students always preparing equipment before starting online learning there are 3 students with a percentage of 50\%. In indicator (2) the percentage of students not committing acts that violate the rules during the learning process there are 3 students, with a percentage of $50 \%$.

\section{CONCLUSION}

It was found from the results of research at SD Negeri 46 Mataram that it can be concluded that student learning independence is in the aspects: Aspects of having self-confidence, it can be concluded that independent learning students are able to ask things they do not understand during the online learning process to get a percentage of 50.33\%. Aspects in making decisions, it can be concluded that students' learning independence is able to develop learning methods to get a percentage of $38.66 \%$. Responsible Aspect, it can be concluded that independent learning Students always collect assignments according to a predetermined time to get a percentage of $50.25 \%$. Aspects Having a competitive desire to advance, it can be concluded that students' learning independence is able to find out things that have not been understood and students always maintain themselves during teaching and learning activities to get a percentage of $44.66 \%$. Aspects of discipline can be concluded that students do not commit acts that violate the rules during the online learning process get a percentage of $41.5 \%$. It was found from the results of research at SD Negeri 46 Mataram that it can be concluded that the difficulty factor in student learning independence during the covid-19 pandemic is in the aspects: the difficulty factor of students' learning independence in having self-confidence, it can be concluded that students have difficulty expressing opinions and students the difficulty of asking things that they did not understand during the online learning process got a percentage of $44.33 \%$. the difficulty factor for students' learning independence in making decisions, it can be concluded that students have difficulty in making decisions to look back at the answers given to get a percentage of $36.66 \%$. the difficulty factor for students' learning independence in being responsible, it can be concluded that students have difficulty seriously in participating in learning, students have difficulty in collecting assignments according to a predetermined schedule, students find it difficult to be responsible for completing assignments getting a percentage of $45.75 \%$. difficulty factor in student learning independence Having a competitive desire to advance, it can be concluded that students have difficulty finding out things that have not been understood during teaching and learning activities to get a percentage of $38.66 \%$. The difficulty factor for learning independence in discipline can be concluded that students have difficulty preparing equipment before starting online learning, students commit acts that violate the rules during the online learning process to get a percentage of $50 \%$.

\section{RECOMMENDATION}

Teachers must be able to implement the basic principles of teaching skills, one of which is holding variation skills. The variation of learning carried out by the teacher can carry out at least three parts, namely variations in teaching styles, use of media, and patterns of interaction. 


\section{REFERENCES}

Abbas, A., \& Hidayat, M. Y. (2018). Faktor-faktor kesulitan belajar fisika pada peserta didik kelas IPA sekolah menengah atas. Jurnal Pendidikan Fisika, 6(1), 45-50.

Ali, M., \& Asrori, M. (2019). Psikologi remaja: Perkembangan peserta didik.

Aqib, Z. (2013). Model-model, media, dan strategi pembelajaran kontekstual (inovatif). Bandung: yrama widya.

Arikunto, S. (2010). Prosedur Penelitian: Suatu Pendekatan Praktik (Edisi Revisi). Jakarta: Rineka Cipta.

Aswan, Z., \& Syaiful, D. B. (2010). Strategi belajar mengajar. Jakarta: Rineka Cipta.

Baumgartner, L. M. B. L. M. (2003). Self-Directed Learning. Adult Learning Theory, 23.

Dzhengiz, T. (2020). A literature review of inter-organizational sustainability learning. Sustainability, 12(12), 4876.

Erfita, F., Suntoro, I., \& Yanzi, H. (2018). Pengaruh Iklim Sekolah Dan Konsep Diri Terhadap Pembentukan Sikap Tanggung Jawab. Jurnal Kultur Demokrasi, 5(9).

Fathoni, A. (2006). Metodologi Penelitian dan Teknik Penyusunan. Skripsi. Jakarta: PT Rineka Cipta.

Gunawan, G., Purwoko, A. A., Ramdani, A., \& Yustiqvar, M. (2021). Pembelajaran Menggunakan Learning Management Systemberbasis Moodle pada Masa Pandemi Covid-19. Indonesian Journal of Teacher Education, 2(1), 226-235.

Hasibuan, A. M., Saragih, S., \& Amry, Z. (2019). Development of Learning Materials Based on Realistic Mathematics Education to Improve Problem Solving Ability and Student Learning Independence. International electronic journal of mathematics education, 14(1), 243-252.

Hidayat, D. R., Rohaya, A., Nadine, F., \& Ramadhan, H. (2020). Kemandirian belajar peserta didik dalam pembelajaran daring pada masa pandemi COVID-19. Perspektif Ilmu Pendidikan, 34(2), 147-154.

Isnaeni, S., Fajriyah, L., Risky, E. S., Purwasih, R., \& Hidayat, W. (2018). Analisis kemampuan penalaran matematis dan kemandirian belajar siswa SMP pada materi persamaan garis lurus. Journal of Medives: Journal of Mathematics Education IKIP Veteran Semarang, 2(1), 107-116.

Jufri, W. (2013). Belajar dan pembelajaran sains. Bandung: Pustaka Reka Cipta.

Kusrini, W., \& Prihartanti, N. (2014). Hubungan dukungan sosial dan kepercayaan diri dengan prestasi bahasa inggris siswa kelas viii smp negeri 6 boyolali. Jurnal Penelitian Humaniora, 15(2), 131-140.

Maksum, A., \& Lestari, I. (2020). Analisis Profil Kemandirian Belajar Mahasiswa Di Perguruan Tinggi. Parameter: Jurnal Pendidikan Universitas Negeri Jakarta, 32(1), 75-86.

Moleong, L. J. (2007). Metodologi penelitian kualitatif edisi revisi.

Ng, B. L., Liu, W. C., \& Wang, J. C. (2016). Student motivation and learning in mathematics and science: A cluster analysis. International Journal of Science and Mathematics Education, 14(7), 1359-1376.

Parker, D. K. (2006). Menumbuhkan Kemandirian dan Harga Diri Anak.

Ramdani, A., Artayasa, I. P., Yustiqvar, M., \& Nisrina, N. (2021). Enhancing prospective teachers' creative thinking skills: A study of the transition from structured to open inquiry classes. Cakrawala Pendidikan, 40(3).

Riyanda, A. R., Herlina, K., \& Wicaksono, B. A. (2020). Evaluasi Implementasi Sistem Pembelajaran Daring Fakultas Keguruan dan Ilmu Pendidikan Universitas Lampung. IKRA-ITH HUMANIORA: Jurnal Sosial Dan Humaniora, 4(1), 66-71.

Soenarko, I. G. K., Andayani, Y., \& Junaidi, E. (2018). Keterampilan pengambilan keputusan dan hasil belajar kimia siswa di SMA/MA Negeri Mataram ditinjau dari penerapan metode pembelajaran. Jurnal Pijar Mipa, 13(2), 86-89.

Sundayana, R. (2016). Kaitan antara gaya belajar, kemandirian belajar, dan kemampuan pemecahan masalah siswa SMP dalam pelajaran matematika. Mosharafa: Jurnal Pendidikan Matematika, 5(2), 75-84.

Yamin, M. (2013). Strategi \& Metode Dalam Pembelajaran. Jakarta: GP Press Grup. 